電子線トモグラフィー法による結晶性材料の解析*

金 子 賢 治*1

\title{
Characterization of Crystalline Materials by Electron Tomography
}

\author{
Kenji KANEKO*1
}

${ }^{* 1}$ Department of Materials Science and Engineering, Kyushu University, 744 Motooka, Nishi, Fukuoka, 819-0395, Japan

\author{
(Received April 26, 2010, Accepted June 9, 2010)
}

\begin{abstract}
Combination of transmission electron microscopy and computed tomography (TEM-CT) is a powerful technique to characterize three-dimensional nature of materials. In this paper, its principle and application are described in detail. In addition, as an example, TEM and TEM-CT was applied on TiN-Ag nanocomposite synthesized by dc arc-plasma method. Microstructures of TiN-Ag nanocomposite were carefully characterized by TEM, and nano-morphologies by TEM-CT. It was found that the surface of nanocrystalline TiN matrix was covered by finely dispersed Ag nanoparticles, and it was found that they were physically attached but not chemically bonded. From these experimental results, formation mechanisms are also predicted.
\end{abstract}

\section{1. はじめに}

生活基盤を支える金属材料や無機材料からなる様々な結晶 性材料に我々の生活は依存している。これらの材料の特性 は，原子スケールからミクロン〜ミリメートルオーダーの階 層的な構造に依存している. 例えば, 結晶構造・組成・結合 状態・粒子サイズや形態などが結晶性材料の特性に影響を与 える因子としてあげられる。ほとんどの結晶性材料は多結晶 として存在し, 多くの結晶粒から構成されているため, 結晶 粒界, 転位, 格子欠陥などの内部構造や相変態, 粒界すべ り, 再結晶化などの内部状態の変化などが特性に大きく影響 を及ぼす。更には, 不純物や添加物, それに伴う析出物の微 細構造や形態も材料の特性を大きく左右する. これらの因子 を一つ一つ丹念にナノスケールオーダーで制御・解析するこ とにより，漸く期待される特性を持つ新規材料の創製や特性 の改善を行うことが可能となる.このような重要な因子を解 析するために最も有効な手法として, 顕微鏡, 特にナノメー トルスケールの構造を観察することのできる「透過型電子顕 微鏡 $(\mathrm{TEM}) 」$ が挙げられる.

通常, TEM を用いて材料解析を行う場合, 2 次元透過像 や電子線回折パターンを得ることが可能である. 透過像には 物質の組織や組成, 構造に応じたコントラストが含まれ, 電 子線回折パターンには結晶構造や結晶方位などの情報が含ま れているため, これらの情報を組久合わせることにより, 試 料内部の様々な情報をサブナノスケールの空間分解能で得る ことが可能となる.

しかし,このようにして得られた 2 次元透過像や電子線 回折パターンから, 真の 3 次元形態を正確に把握すること は非常に困難であるうえ, 異方性を持つ材料の 3 次元形態 と材料の特性とを関連づけることは殆ど不可能である。 た，多くの実用材料は多元素からなる多層膜や多結晶といっ た複雑な形態や構造を有しているため, ナノスケールの 3

* 平成 22 年 2 月 5 日 2009 年度 NIMS ナノ計測センターシンポジ ウムで発表

*1 九州大学大学院工学研究院材料工学部門 (干819-0395 福岡 県福岡市西区元岡744)
次元情報を解析する手法が望まれていた.

現在, 内部の複雑な立体的情報を得る手法として, 3 次元 アトムプローブ法（原子オーダー〜数 $\mathrm{nm}$ ), 電子線トモグ ラフィ（TEM-CT 法, 数 $\mathrm{nm}$ 数 $\mu \mathrm{m}), \mathrm{SEM}-\mathrm{FIB}$ 法（数 $\mu \mathrm{m} \sim 100 \mu \mathrm{m}$ ）やX 線-CT（数 $\mu \mathrm{m} \sim$ 人体でも可）が挙げら れる.これらの手法の中でも, 今回, ナノスケールの空間分 解能で立体的情報を解析することが可能な TEM-CT 法に関 して解説する.

\section{TEM-CT 法の原理 ${ }^{1)}$}

TEM-CT 法の原理は基本的に医療分野における X 線-CT 法などによる断層撮影法と同一である. 医療用 X 線-CT 法 の場合, $\mathrm{X}$ 線源と X 線検出器が観察対象物体 (人間) を中 心に同期的に旋回するのに対し，TEM-CT 法は電子線に対 して試料を傾斜させる手法である.

TEM-CT 法では, 試料を高角度に傾斜させながら（最大 傾斜角度: $60^{\circ} \sim 90^{\circ}$ ), 連続的に TEM 像や走查 TEM 像 (STEM 像) を撮影し, 得られた一連の連続傾斜像からその 切片の 3 次元情報を再構築する. 実験の具体的なプロセス は, (1)連続傾斜像の撮影と (2) 3 次元像の再構築に二分され る. 最近では, ソフトウェアの発達とともに, TEM や STEM による連続傾斜像の撮影がほぼ自動化されつつあ り，傾斜時の位置ずれや焦点ずれを観察時に補正しながら， 約 2 時間程度で100枚以上の画像が撮影可能となりつつある.

連続傾斜像から断面像を再構築するにあたって，「実際に 得られた 3 次元物体の 2 次元投影像」と「再構築した 3 次 元物体の 2 次元断面像」が等しくなるように補正する必要 がある. 両者の一致を実現するために, 現在までに様々な解 析的および代数的再構成法が試みられ, 解析的手法としては 逆投影法（BP）法やフィルター付き逆投影法（FBP）法が， 代数的手法としては, 代数的画像再構成法 (ART) 法や代 数的反復法 (SIRT) 法が挙げられる. 解析的手法は投影像 を重ね合わせる単純な手法であるのに対し, 代数的手法では 再構成においてある評価関数を設け, その評価関数の值が最 小（または最大）になるように, 再構成画像の修正を繰り返 し行う手法である. 


\section{TEM-CT 法の課題}

TEM-CT 法や TEM 法に用いる試料は，観察領域が広範 囲にわたることや，電子が試料を透過する必要があることか ら，薄膜である場合がほとんどである．このような薄膜試料 の場合，未傾斜時に抢ける厚みを仮に $\mathrm{t}_{0}$ とすると，傾斜時 （）には射電子線に対して見かけ上の試料厚み $(\mathrm{t})$ が $\mathrm{t}_{0} /$ $\cos \theta$ となる. また, 試料がナノ粒子の場合, 非晶質力ーボ ン膜が張られたマイクログリッドに保持したり，ミクロトー ム処理したりするため, 傾斜時におけるカーボン膜の厚みも 考慮する必要がある.この結果, 入射電子が試料のみならず カーボン膜と相互作用を起こし, 非弾性散乱電子の成分が増 加し, 色収差の影響のため, 像質が低下してしまう。この場 合は, 非弾性散乱成分を除去するエネルギーフィルターを併 用することにより像質の改善が可能となる. また，意図的に 非弾性散乱成分を選択することにより，特定の元素の連続傾 斜像の撮影も可能となる ${ }^{2)}$.

また，FIB法を用いて軸の回転方向に対して均一厚みを 持つようにピラー状に試料を加工し, 試料傾斜時に試料厚み の影響が現れないようにする等, 試料作製の面での工夫が凝 らされるようになってきている3).

再構築像の空間分解能と像質は, それぞれの投影像の空間 分解能だけでなく，傾斜角度範囲や角度刻みに大きく依存す る. 角度刻みが小さいほど, 再構築像の像質は向上し, 傾斜 角度範囲が大きければ大きいほど, より多くの情報を含む再 構築像を得ることが可能となる.

試料ステージや試料形状による角度制限の結果, 投影像が ある角度範囲にわたって久落してしまうと, フーリエ空間中 ではこの方向の情報が不足することになる. この結果, 物体 の逆変換はこの情報の欠落方向に対して, 像がぼやけたもの となり像質が低下してしまう。 それ故, TEM-CT 法には高 精度なステージと特別に高傾斜用に設計された試料ホルダー が必要となる4)。また，二軸傾斜を用いる等により情報量を 増加することにより, 良質の 3 次元再構築像を得ることが 可能となる. 最近では, 試料を FIBによりピラー状に加工 し， $\pm 90^{\circ}$ 傾斜させる手法も編み出されてきている3 ${ }^{3)}$.

空間分解能や再構築像の像質を向上させるためには, 多数 の連続傾斜像が必要となり, 長時間にわたる撮影時間が必要 となり, 電子線による試料損傷や試料污染の可能性が出現す る. また, 撮影の際に各傾斜像を十分に位置補正した場合で あっても, 得られた一連の画像に対し, 電子線照射による試 料の変形や試料高さの変化に伴う焦点合わせ操作のため, 傾 斜軸が回転してしまうことがあるため, 注意を要する必要が ある。

\section{4. 観察例：アークプラズマ法により作製した窒 化チタニウム複合粒子5)}

アークプラズマ法とは, 金属をガス中でアーク溶解させ, 金属の蒸発が促進される特性を利用し，ナノ粒子を生成する 方法である ${ }^{6)}$.この手法により，合金を原料とする複合ナノ 粒子を生成することが可能となる. 生成された複合ナノ粒子 は, 原料に用いる金属と雰囲気中の気体との親和力などの違
いから構造が変化することが期待される．窒素との親和力が 大きい Ti と Ag からなる合金を出発原料とし, 雰囲気に $\mathrm{N}_{2}$ を含む $\mathrm{H}_{2}-\mathrm{Ar}$ を用い, 生成した窒化チタニウム（TiN）と 銀 $(\mathrm{Ag})$ からなる複合ナノ粒子の構造を解析することを目 的とした。

出発原料には, TiAgの二元合金を用いた. TiAg 合金を $\mathrm{H}_{2}-\mathrm{Ar}-\mathrm{N}_{2}$ の雾囲気中で直流アーク溶解させ, 蒸発及び凝縮 させることにより複合ナノ粒子を生成し，TEMによる微構 造解析や TEM-CT 法による 3 次元解析を行った.

Fig. 1 は生成した複合ナノ粒子の TEM 像である. 立方 体状のナノ粒子の表面に微細な粒子が付着している様子が伺 える. また, Fig. 2 は立方体状の複合粒子の高分解能像で ある、これより, 立方体の周辺部に $\mathrm{Ag}$ が TiN と反応せず に付着していることが判明した. Fig. 3 には 3 次元再構築

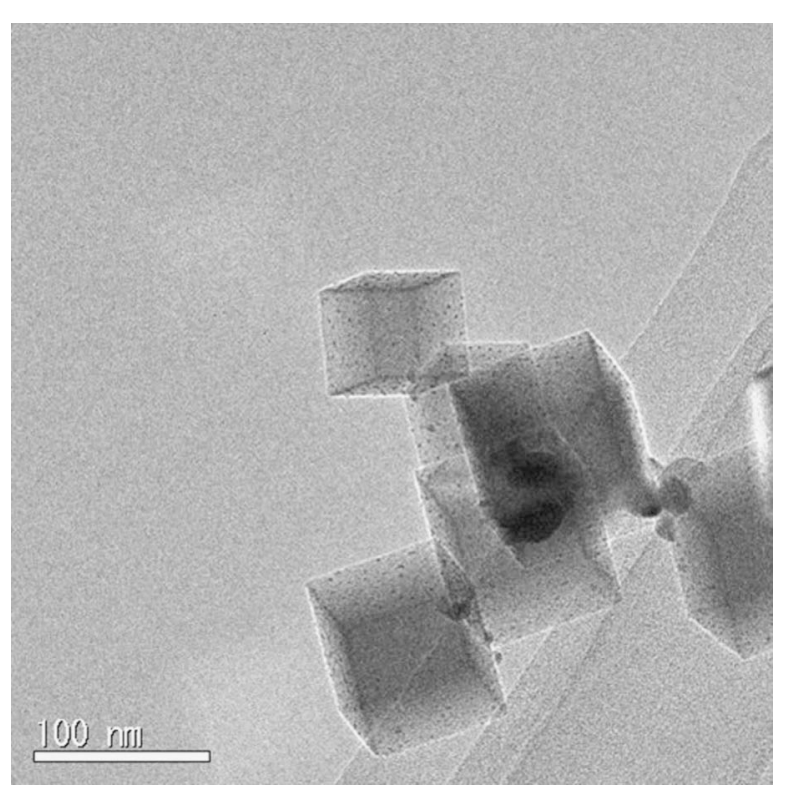

Fig. 1 BF-TEM image of TiN-Ag nanocomposite.

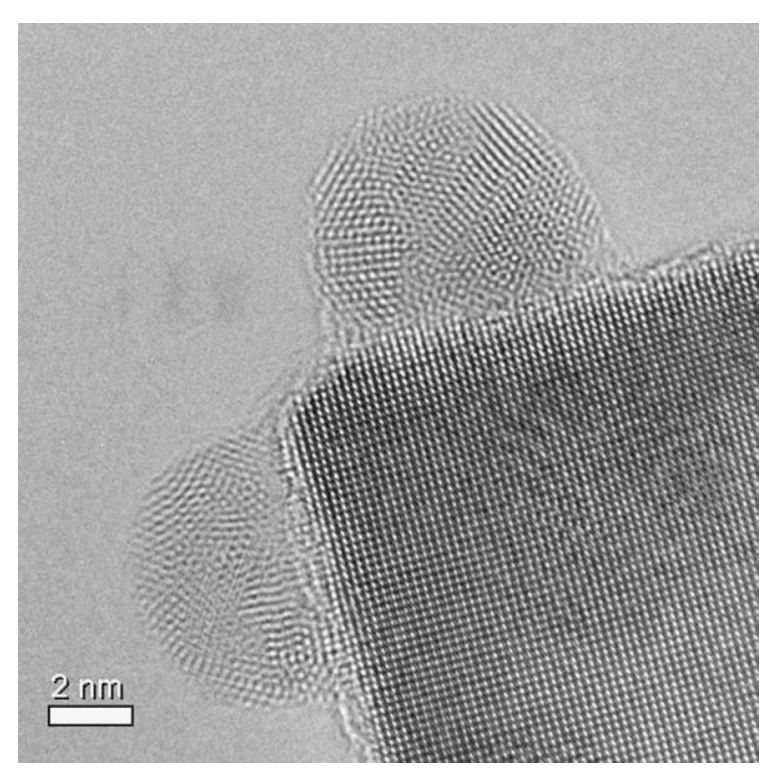

Fig. 2 HR-TEM image of TiN-Ag nanocomposite. 


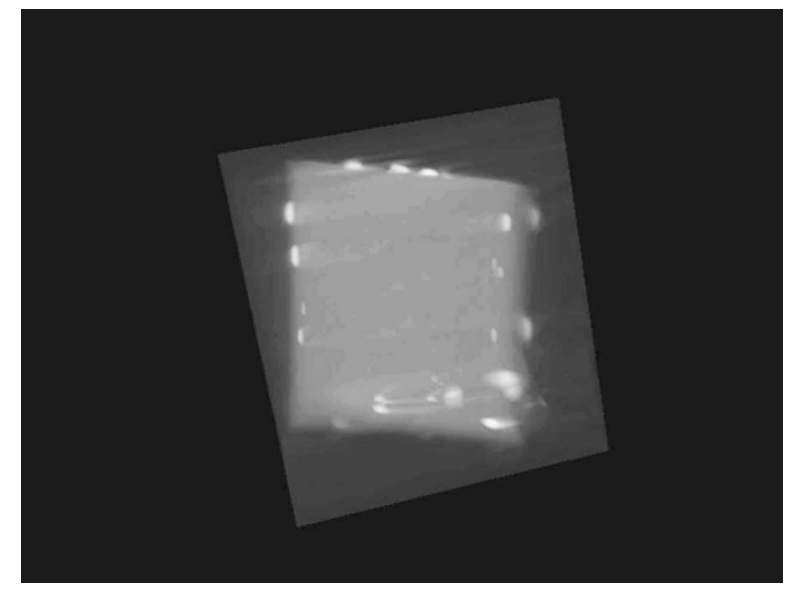

Fig. 3 Three-dimensional morphology of TiN-Ag nanocomposite.
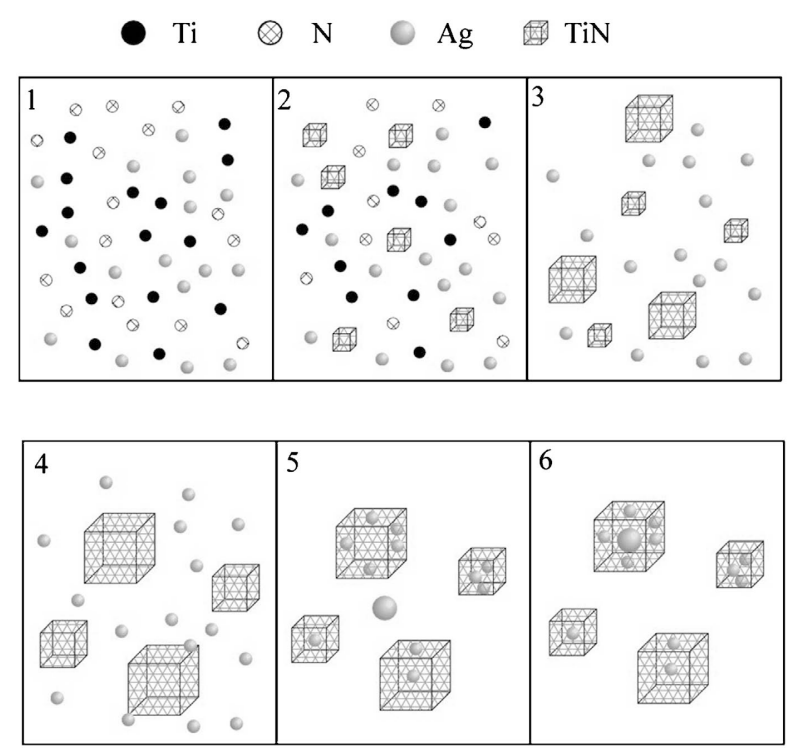

Fig. 4 Schematic diagram of formation mechanism of TiN$\mathrm{Ag}$ nanocomposite prepared by dc arc-plasma method.
像を示す。これらの結果から Fig. 4 に示すようなナノ複合 粒子の形成メカニズムが判明している.

\section{5. 最 後 に}

今回紹介した TEM-CT 法は, 従来の 2 次元 TEM 解析だ けでは解明することが不可能であった立体的情報を得ること が可能であることから，新材料の開発や材料の新知見を得る ため，更なる研究展開が期待されている.

本稿で使用したデータの測定と解析に関しては古河スカイ 侏の北脇幸太郎氏, 物質 ·材料研究機構の目義雄博士, 奥山 秀男氏の協力を得をした。ここに記して謝意を表します。

[文献]

1) N. Baba and E. Katayama: Ultramicroscopy, 108 (2008) 239.

2) P. A. Midgley and M. Weyland: Ultramicroscopy, 96 (2003) 413.

3) N. Kawase, M. Kato, H. Nishioka and H. Jinnai: Ultramicroscopy, 107 (2007) 8.

4) http://www.melbuild.com/

5) K. Kitawaki, K. Kaneko, K. Inoke, J. C. Hernandez-Garrido, P. A. Midgley, H. Okuyama, M. Uda and Y. Sakka: Micron, 40 (2009) 308.

6) Y. Sakka and S. Ohno: Nanoparticles. Nanostruct. Mater., 7 (1996) 341. 